\title{
First record of Trypanosoma sp. (Protozoa: Kinetoplastida) in tuvira (Gymnotus aff. inaequilabiatus) in the Pantanal wetland, Mato Grosso do Sul State, Brazil
}

Primeiro registro de Trypanosoma sp. (Protozoa: Kinetoplastida) em tuvira (Gymnotus aff. inaequilabiatus) no Pantanal, Mato Grosso do Sul, Brasil

Santiago Benites de Pádua ${ }^{1}$; Márcia Mayumi Ishikawa ${ }^{2 *}$; Fabiana Satake ${ }^{3}$; Gabriela Tomas Jerônimo ${ }^{4}$; Fabiana Pilarski ${ }^{1}$

${ }^{1}$ Centro de Aquicultura, Universidade Estadual Paulista - UNESP

${ }^{2}$ Embrapa Agropecuária Oeste, Empresa Brasileira de Pesquisa Agropecuária - EMBRAPA

${ }^{3}$ Centro de Ciências Agrárias, Universidade Federal da Paraíba - UFPB

${ }^{4}$ Laboratório AQUOS, Departamento de Aquicultura, Universidade Federal de Santa Catarina - UFSC

Received December 7, 2010

Accepted January 24, 2011

\begin{abstract}
The blood infection by Trypanosoma sp. in tuvira (Gymnotus aff. inaequilabiatus) from the Pantanal wetland was reported in this study. Ten fish from the Paraguay River in the Pantanal were evaluated for the presence of hemoflagellates. Trypomastigotes of Trypanosoma sp. were observed in blood smears from three fish (30\% prevalence) and some forms were seen to be undergoing division. Using the diagnostic methods of fresh examination and blood centrifugation in hematocrit capillary tubes, the prevalence rate was $80 \%$. This is the first report of Trypanosoma sp. in tuvira in Brazil.
\end{abstract}

Keywords: Hemoflagellate, hemoprotozoa, live bait.

\section{Resumo}

O objetivo do presente estudo foi reportar a infecção por Trypanosoma sp. em tuviras (Gymnotus aff. inaequilabiatus) oriundas do Pantanal Sul-mato-grossense, Brasil. Dez peixes provenientes do rio Paraguai, Pantanal Sul-mato-grossense, foram avaliados quanto à presença de hemoflagelados. Tripomastigotas de Trypanosoma sp. foram observados nas extensóes sanguíneas de três peixes (30\% de prevalência), e algumas formas encontravam-se em divisão. Por meio do exame a fresco e da centrifugação do sangue em capilar de hematócrito como métodos para diagnóstico, a taxa de prevalência foi de $80 \%$. Esse é o primeiro relato de Trypanosoma sp. em tuviras no Brasil.

Palavras-chave: Hemoflagelado, hemoprotozoário, isca viva.

\section{Introduction}

Trypanosomes are kinetoplastid protozoa that cause blood infection in many species of fish worldwide, including both freshwater species (FIGUEROA et al., 1999; SMIT et al., 2004; GU et al., 2007; KONAS et al., 2010) and marine species (SAUNDERS, 1959; OVERATH et al., 1999; KARLSBAKK, 2004; BURRESON, 2007). Transmission of these hemoflagellates between fish has been attributed to different species of leeches. The leech Hemiclepsis marginata is responsible for transmission of T. carassii among European carp (OVERATH et al., 1999). In Canada, Actinobdella inequiannulata is the most abundant leech species

\footnotetext{
*Corresponding author: Márcia Mayumi Ishikawa

Doutorado em Parasitologia Veterinária, Laboratório de Piscicultura,

Embrapa Agropecuária Oeste, BR 163, Km 253,6, CP 661,

CEP 79804-970, Dourados - MS, Brazil;

e-mail:marcia@cpao.embrapa.br
}

and is the specific vector of T. catostomi for Catostomus commersoni (JONES; WOO 1992). The main vector of trypanosomiasis in fish belonging to the family Loricariidae in Brazil is the leech Batracobdella gemmata (D'AGOSTO; SERRA-FREIRE 1993).

The tuvira (Gymnotus aff. inaequilabiatus) (Teleostei: Gymnotidae) is a knifefish native species in the Pantanal basin that inhabits lentic environments, with turbid water and aquatic vegetation that is rich in organic matter coming from the flooding process. This species has economic importance because of its use as live bait, driven by the demand for sport fishing in the Pantanal, such as for the dourado (Salminus brasiliensis) and for two catfish species: pintado (Pseudoplatystoma corruscans) and cachara (Pseudoplatystoma reticulatum). However, constant exploitation has caused its numbers to diminish in its natural environment (MORAES; ESPINOSA, 2001). Production in captivity may be 
an economic alternative for riverbank peoples, and it may diminish the capture pressure on the natural environment. However, lack of information about health issues relating to tuvira has limited their rearing.

The aim of the present study was to report the blood infection by Trypanosoma sp. in tuvira ( $G$. aff. inaequilabiatus) from the Pantanal wetland, Mato Grosso do Sul State, Brazil.

\section{Material and Methods}

Tuvira specimens that had been caught by bait gatherers in the Paraguay river ( $18^{\circ} 04^{\prime} 15,00^{\prime \prime} \mathrm{S}$ and $57^{\circ} 28^{\prime} 17,00^{\prime \prime} \mathrm{W}$ ), in the Pantanal, and had been put on the market in the Corumbá city, were acquired and transported to the Fish-farming Laboratory of Embrapa Western Region Agriculture, located in the Dourados, Mato Grosso do Sul State. The fish were kept in round fiberglass tanks with $1000 \mathrm{~L}$ of capacity, which were supplied with a continuous flow of water coming from an artesian well $\left(10 \mathrm{~L} \cdot \mathrm{min}^{-1}\right)$.

To diagnose the presence of hemoflagellates, ten fish specimens were subjected to venous puncture of the caudal vein, to collect blood. Blood smears on slides were produced in duplicate and stained panchromatically with the May Grünwald-GiemsaWright combination, and were then evaluated under an optical photomicroscope (Nikon ${ }^{\circledR}$ E200, Japan). Fresh blood between a slide and a coverslip was also examined, by means of phase contrast microscopy (Nikon E200, Japan). The same procedure was used for observations after centrifugation of blood samples in hematocrit capillary tubes, just above the white blood cell layer (WOO, 1969).

\section{Results and Discussion}

Trypomastigotes of Trypanosoma sp. were observed in the blood smears from three fish (30\%) (Figure 1a, b), and some of them were found to be undergoing division (Figure 1d). From evaluating both the fresh samples and the results from centrifugation of blood samples in hematocrit capillary tubes, from the same fish specimens, the prevalence rate was found to be $80 \%$ (Figure 1c, d). This characterized the most efficient method for diagnosis.

The prevalence rate of these blood parasites is generally high in fish from the natural environment (OVERATH et al., 1999; SMIT et al., 2004; KONAS et al., 2010). This is possibly related to the immunity mechanisms of the fish against infections. Overath et al. (1999) stated that the immune response of nonmammalian vertebrates is of limited efficacy and/or these parasites evade or manipulate the immune response of their respective hosts.

Multiplication of these hemoflagellates in blood tissue has been described in some vertebrate hosts (PATERSON; WOO, 1984; BURRESON; KARLSBAKK, 2007). This division may be an adaptive mechanism, if the pathogenicity of these trypanosomes for their hosts is dependent on the intensity of the parasitemia (BURRESON; KARLSBAKK, 2007).
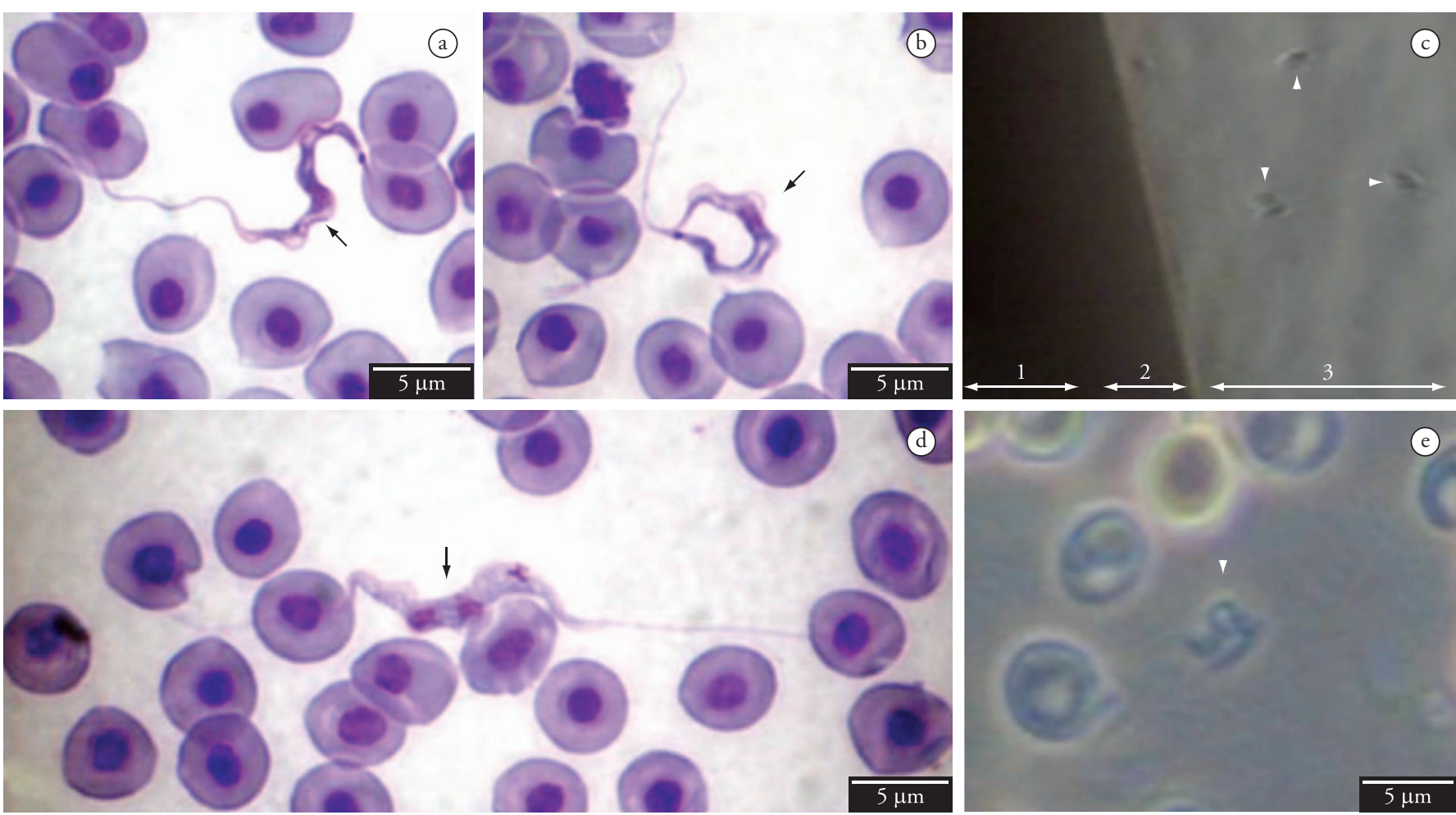

Figure 1. Trypanosoma sp. in the circulating blood of tuvira (Gymnotus aff. inaequilabiatus) from the Pantanal wetland, State of Mato Grosso do Sul. Trypomastigotes (a-b) and stage undergoing division (d). May-Grünwald-Giemsa-Wright staining, bar $=5 \mu \mathrm{m}$. Trypomastigotes observed after centrifugation of blood in a capillary tube (c - 1: red blood cells; 2: white blood cell paste; 3: plasma). Magnification 100×. Trypanosoma observed through direct examination by means of phase contrast microscopy (e). Bar $=5 \mu \mathrm{m}$. 


\section{Conclusion}

This is the first report of Trypanosoma sp. in tuvira in Brazil. Additional studies need to be conducted in order to identify this parasite systematically and molecularly, and to identify its biological cycle, pathogenicity and impact on tuvira populations in the natural environment and on populations reared by bait gatherers.

\section{Acknowledgements}

The authors thank Dr. M.A. Rotta for supplying and transporting the fish used in this study and the Fundação de Apoio ao Desenvolvimento do Ensino, Ciência e Tecnologia do Estado de Mato Grosso do Sul (FUNDECT) for financial support.

\section{References}

BURRESON, E. M. Hemoflagellates of Oregon marine fishes with the description of new species of Trypanosoma and Trypanoplasma. Journal of Parasitology, v. 93, n. 6, p. 1442-1451, 2007.

BURRESON, E. M.; KARLSBAKK, E. Multiplication of Trypanosoma pacifica (Euglenozoa: Kinetoplastea) in the English sole, Parophrys vetulus, from Oregon coastal waters. Journal of Parasitology, v. 93, n.4, p. 932-933, 2007.

D'AGOSTO, M.; SERRA-FREIRE, N. M. Estádios evolutivos de tripanossomas de Hipostomus punctatus Valenciennes (Osteichthyes, Loricariidae) em infecção natural de Batracobdella gemmata Blanchard (Hirudinea, Glossiphoniidae). Revista Brasileira de Zoologia, v. 10, n. 3, p. 417-426, 1993.

FIGUEROA, F. et al. Fish trypanosomes: their position in kinetoplastid phylogeny and variability as determined from $12 \mathrm{~S}$ rRNA kinetoplast sequences. The Journal of Eukaryotic Microbiology, v. 46, n. 5 , p. 473-481, 1999.

GU, Z. M. et al. Morphological and genetic differences of Trypanosoma in some Chinese freshwater fishes: difficulties of species identification. Parasitology Research, v. 101, n. 3, p. 723-730, 2007.

JONES, S. R. M.; WOO, P. T. K. Vector specificity of Trypanosoma catostomi and its infectivity to freshwater fishes. Journal of Parasitology, v. 78, n. 1, p. 87-92, 1992.

KARLSBAKK, E. A trypanosome of Atlantic cod, Gadus morhua L., transmitted by the marine leech Calliobdella nodulifera (Malm, 1863) (Piscicolidae). Parasitology Research, v. 93, n. 2, p. 155-158, 2004.

KONAS, E. et al. Occurrence of Trypanosoma sp. in wild African sharptooth catfish (Clarias gariepinus Burchell, 1822) from River Asi (north-eastern Mediterranean), Turkey. Turkish Journal of Zoology, v. 34, n. 2, p. 271-273, 2010.

MORAES, A. S.; ESPINOZA, L. W. Captura e comercializaçáo de iscas vivas em Corumbá, MS. Corumbá: Embrapa Pantanal, 2001. 37 p. (Boletim de pesquisa, 21).

OVERATH, P. et al. Freshwater fish trypanosomes: definition of two types, host control by antibodies and lack of antigenic variation. Parasitology, v. 119, n. 6, p. 591-601, 1999.

PATERSON, W. B.; WOO, P. T. K. Ultrastructural studies on mitosis in Trypanosoma danilewskyi (Mastigophora: Zoomastigophorea). Canadian Journal of Zoology, v. 62, n. 6, p. 1167-1171, 1984.

SAUNDERS, D. C. Trypanosoma balistes n. sp. from Balistes capriscus Gmelin, the Common Triggerfish, from the Florida Keys. Journal of Parasitology, v. 45, n. 6, p. 623-626, 1959.

SMIT, N. J. et al. Fish trypanosomes from the Okavango Delta, Botswana. Folia Parasitologica, v. 51, n. 4, p. 299-303, 2004.

WOO, P. T. K. The haematocrit centrifuge for the detection of trypanosomes in blood. Canadian Journal of Zoology, v. 47, n. 5, p. 921-923, 1969. 